\title{
ENVIRONMENTAL MANAGEMENT SYSTEMS AND CONSTRUCTION SMES: A CASE STUDY FOR SLOVENIA
}

\author{
Jana Šelih \\ Faculty of Civil and Geodetic Engineering, University of Ljubljana, Jamova 2, 1000 Ljubljana, Slovenia \\ E-mail: jselih@fgg.uni-lj.si \\ Received 12 Sept 2006; accepted 15 Jan 2007
}

\begin{abstract}
Construction projects and activities are, in general, associated with a wide range of environmental impacts. Therefore the principles of sustainable development should be adopted during construction just like in any other industrial sector. At the organisation's level, one of the ways of achieving this goal is by implementing an environmental management system (EMS). The purpose of the paper is to present current environmental management trends in construction companies based on a recent study conducted for the construction industry in Slovenia, and in particular to report on how the construction SMEs perceive obstacles to the EMS implementation. The benefits and obstacles associated with ISO 14001-compliant EMS implementation are discussed, and the results of the survey related to environmental management systems (QMS) in construction companies in Slovenia are presented and analysed. They indicate that the majority of responding construction companies has implemented QMS, and $46 \%$ of the respondents have also established an EMS. It can be observed that, in relative terms, there are less SMEs with an EMS than larger companies with EMS; SMEs tend to see the required documentation accompanying the EMS as excessive and a major barrier for its implementation. In practice, these findings are important because they can be used to define the baseline for new initiatives that promote EMSs within construction SMEs.
\end{abstract}

Keywords: construction industry, SMEs, environmental management system, quality management system, ISO 14000 , survey, Slovenia.

\section{Introduction}

Over the past two decades, due to increasing global environmental awareness, construction activities have had raised serious concerns about their large environmental impacts, which stem from their consumption of materials, many of which are non-renewable. It is estimated that buildings account for about $40 \%$ of the materials entering the world's economy each year and for $25 \%$ of the world's usage of wood [1]. In addition, site construction produces many atmospheric pollutants, and negligence on construction sites may result in the spillage of substances, which are washed away into water sources. Large volumes of waste result from the production, transport, use of construction materials and products. Large amounts of energy are consumed during manufacturing construction products. Emissions to air are created during the transport of these products from the factory to the construction site. It is therefore clear that construction activities can have a large adverse impact upon the environment. This impact may be even more profound when it is taken into the account that the construction site is a temporary production facility, predominantly exposed to outdoor conditions, with a large number of personnel belonging to different companies with very different organisational cultures. As a consequence, production processes take place in a less controlled and more vulnerable environment, when compared to other industrial settings; thus the risk of considerable environmental damage is increased.

From the above discussion it is clear that construction companies need to use a systematic approach to environmental management. This can be carried out by establishing at organisation's level a formal structure that implements environmental management, the so-called environmental management system (EMS).

An EMS involves the formal system and database, which integrates procedures and processes for the training of personnel, monitoring, summarising, and reporting of specialised environmental performance information to internal and external stakeholders of the company. The documentation of this environmental information is primarily focussed on design, pollution control and waste minimisation, training, reporting to top management, and setting goals [2]. The system may follow specifications of an existing standard, eg ISO 14001, as will be discussed in the following chapter.

\subsection{Development of the ISO 14000 series of standards}

Global environmental awareness grew from its embryonic state in the mid-80s, and in this respect the socalled Brundtland report [3] published by the World Commission on Environment and Development was highly influential and it provided for the environmental activities a global framework. The report deals with 
sustainable development and the change of politics needed for its achievement. The first common specifications for EMS [3] were established in 1992, and they had their origin in the UK by adopting the BS 7750 standard [4]. In the European Union, the next step occurred in 1995 when the European Commission issued the Council Regulation (EEC) No 1836/93, which resulted in the introduction of the EMAS (Eco Management and Audit Scheme).

Worldwide, the need for a standardized environmental management system for organizations became clear after the Rio de Janeiro summit on the environment in 1992 and the Uruguay round of the GATT negotiations. As a consequence, the first draft of the series of standards ISO 14000 was first published in 1996 and subsequently revised in 2004. The series is today well established throughout the world. In Slovenia, the ISO 14001 standard was adopted as a national voluntary standard in 1997.

The ISO 14000 series cover 6 areas: EMS, environmental auditing and related investigations; environmental labelling; environmental performance evaluation; life-cycle assessment; terminology and definitions. The first standard of the ISO 14000 series, ISO 14001 (2004) [5], is a specification for an EMS. It provides an objective understanding of the environmental aspects and impact of the organisations' activities. Further on, it enables objectives and targets defining the environmental goals to be set, and the path towards achieving them to be formulated [1]. In short, this standard is a voluntary specification to which organisations choose to become certified, and provides guidelines for implementing an EMS.

\subsection{ISO 14000 certification of companies in Europe}

An increasing number of companies worldwide are seeking the ISO 14001 certification, to which, in many cases, they are driven by business requirements; often this certification is perceived as a measure for enhanced competitiveness and prestige. Obviously, there are other factors, such as the magnitude of environmental degradation, general environmental awareness, environmental regula- tions and governmental incentives in a particular country, that influence the actual number of certified companies.

The upward trend of companies with an ISO 14001 certificate in selected European countries from 1995 to 2005 is clearly shown in Table 1 . The data are compiled from $[6,7]$. Close observation of the data indicates that the highest number of certificates was awarded to Swedish companies. Furthermore, the data for 2005 show that the number of organisations holding the ISO 14001 certificate in Slovenia, 212 companies / 1000000 inhabitants, is comparable to the corresponding numbers in countries like Spain (200 companies / 1000000 inhabitants) and Finland (176 companies / 1000000 inhabitants). This trend is expected in the immediate future to be applicable worldwide to both developed and developing economies.

\subsection{Problem statement}

Although the number of organisations with ISO 14001 certificates is large and growing fast, the construction sector lags well behind this general trend. The traditional construction project goals, specified level of quality, completion in time and limitation of costs do not take into account the environmental goals, as proposed in [8]. As already mentioned, there are driving forces that lead to the new paradigm illustrated schematically in Fig 1 [8], and among them, it can be found environmental education and awareness, pressure from clients and governmental regulations, need for improved public image, and stakeholders' involvement; these same forces, at organisation's level, lead to the implementation of an EMS.

Worldwide, projects promoting the EMS implementation in the industry are being initiated by governmental agencies and NGO's. To ensure the success of such projects (ie to achieve an increase of the number of the EMS certificates), the initial environmental awareness level, the main drivers and barriers related to the EMS implementation have to be identified in advance. Furthermore, the outreach should be tailored to the business sector and, most likely, it cannot be or should be not generalised [9].

Table 1. Number of companies holding the ISO 14001 certificate per million inhabitants in selected EU countries [6, 7]

\begin{tabular}{l|rrrrr}
\hline & \multicolumn{5}{c}{ Year } \\
& $\mathbf{1 9 9 7}$ & $\mathbf{1 9 9 9}$ & $\mathbf{2 0 0 1}$ & $\mathbf{2 0 0 2}$ & $\mathbf{2 0 0 5}$ \\
\hline Austria & 9,8 & 19,0 & 27,2 & 52,4 & 58,7 \\
Czech Republic & 0,4 & 5,9 & 17,0 & 31,1 & 207,6 \\
Finland & 28,8 & 89,5 & 130,9 & 142,9 & 175,8 \\
Germany & 4,3 & 11,6 & 40,9 & 44,7 & 53,7 \\
Hungary & 1,2 & 12,0 & 33,7 & 63,4 & 98,3 \\
Italy & 1,8 & 4,2 & 22,3 & 37,1 & 121,9 \\
Lithuania & 0,0 & 0,3 & 6,1 & 9,6 & 60,6 \\
Netherlands & 16,1 & 24,7 & 57,7 & 65,7 & 67,8 \\
Poland & 0,2 & 1,9 & 7,6 & 11,3 & 24,6 \\
Slovenia & 2,5 & 9,7 & 69,1 & 75,7 & 212,0 \\
Spain & 2,1 & 13,3 & 47,9 & 75,0 & 200,2 \\
Sweden & 21,5 & 94,1 & 229,0 & 302,0 & 407,3 \\
\hline
\end{tabular}




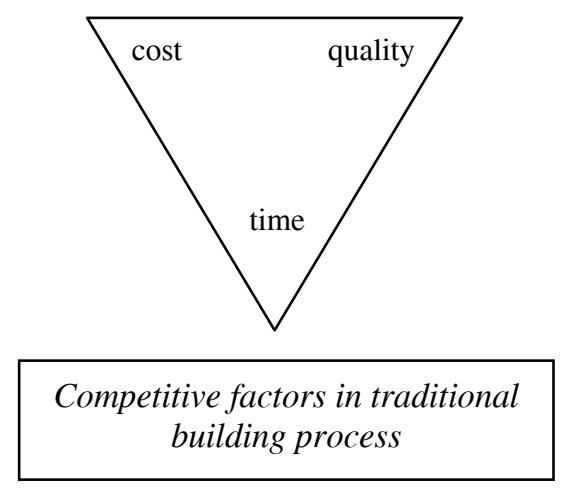

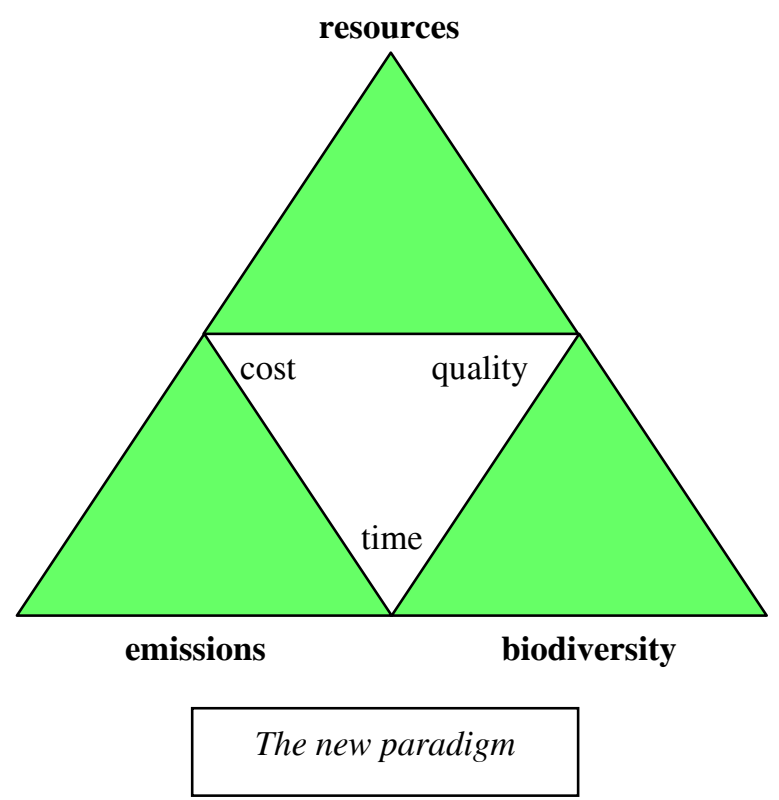

Fig 1. The new paradigm [8]
In what the construction sector is concerned, the approach used in these projects should account for the special features and differences between the construction sector and manufacturing industry. Various participants are encountered in a construction project: the client as the key stakeholder initiating the project, the designer, contracting and subcontracting companies, and various suppliers, consultants. The construction sector is therefore highly fragmented and consists of business entities of various sizes and trades. Further, it can be noticed that a large portion of construction companies can be classified as small- or medium-size enterprises (SMEs).

The approach used to promote the ISO 14001 compliant EMS implementation in any industrial sector has to be different for small and medium enterprises (SMEs) and for large, corporate construction companies [10]. This also holds true for the construction industry. The approach should be formulated on the basis of an empirical determination of construction industry views. The research problem tackled in this paper can be therefore formulated as follows:

- What are the environmental issues on which the construction industry is focussing? Are the construction SMEs focussing on the same issues as the large companies?

- Do the construction SMEs perceive different obstacles to the EMS implementation as the large companies?

Within the context of this paper, the SME is defined as a private enterprise (in manufacturing industry, service or trade) with fewer than 200 employees, which is a simplified version of the official EU definition [11].

\section{Methodology of the study}

First, a literature survey was carried out in order to establish the theoretical background of the general drivers and barriers encountered when implementing the environmental management systems.

The study focus was the Slovenian construction industry, which, in many respects, can be considered representative of the construction industry of the new EU states; for its pursuit, a questionnaire-based survey was developed and then employed in order to gain the necessary data for the Slovenian construction industry. The results obtained, their analysis and interpretation should prove to be also valid for the construction industry of the new EU states.

The data provided by the Slovenian Chamber of Commerce [12] shows that Slovenian construction sector contains a large proportion of SMEs. In 2004, 13274 Slovenian organisations stated "design, engineering and construction" as their main business activity. Out of this number, 13162 companies are small enterprises. Only $112(8,4 \%)$ companies can be classified as medium or large companies. There are only two large contracting companies, SCT d. d. and Primorje d. d., each with more than 1000 employees.

\section{Literature survey}

Two areas of uncertainty are proved to be the major obstacles to the widespread adoption of EMSs by manufacturing companies. The first stems from the ambiguity of the relationship between pollution reduction and profitability. The second arises from the lack of reliable information about the differences in tangible benefits derived from formal, even certified EMSs versus those from an informal or less rigorous set of environmentally focused activities [2]. For a long time, the erroneous view has prevailed that pursuing environmental goals was opposed to a sound business strategy. A conventional consensus held then was that any investment in an improved environmental performance would contribute to penalties 
such as increased lead times, reduced quality or increased costs - all of which reduced the profits [2]. It was only in the 1990's that these views were challenged by various authors (eg [13, 14]); despite considerable debate and some evidence of the contrary, these views are still supported by many sectors [2]. It is a fact that impacts on EMSs as a whole; and in particular their environmental and business performance, are, in general, difficult to assess accurately, and a systematic research in this area is lacking [15]. One of the few studies on this topic [2] empirically confirms the hypothesis that the improved performance (measured by reduction of costs, improved quality, reduction of waste and increased lead times) has been registered after the company introduced a formal EMS.

Implementing an EMS is not a trivial decision, as it requires significant and ongoing staff commitment and effort, increased documentation and paperwork, potential need and introduction of new technologies and large intangible costs related to the organisational change.

In general, the companies decide to establish an EMS because the projected benefits are larger than the projected barriers. The drivers, ie the factors that create or change the organisation's performance, are directly related to the anticipated benefits [9] and they can be divided into internal (arising within the company) and external (arising from the company's environment) drivers. The following general drivers have been identified in the literature [15]:

- Corporate policies are an important external driver, as a large proportion of the companies are encouraged to adopt an EMS by the parent organisation.

- Regulatory expectations, or desire to improve compliance, are one of the strongest external drivers.

- Market forces are extremely important for business entities. Both customer demands and publicrelations benefits, ie improved public image of the company, can be influential drivers for EMS adoption.

- Government assistance can be carried out in various ways. In general, it is assumed that providing financial or expert support during the EMS implementation facilitates the process and is therefore an important external driver.

- Cost reduction is an important internal driver for every business entity and can be achieved by reducing the potential for pollution occurrence.

- Organisational culture is an internal driver that should not be overlooked. If it is positive against the environmental issues, it can encourage the management to initiate the EMS implementation. This makes sense also because the EMS implementation requires a substantial investment into the human resources, and this investment might be lost if it is fundamentally in conflict with the organisation's philosophy of doing business.

In summary, the EMSs can be potentially attractive to the management as it may provide companies with unique environmental resource, capabilities and benefits that can lead to competitive advantages $[16,17]$.

\subsection{Implementing EMS in SMEs: drivers and barriers}

In the early years of the ISO 14001 adoption, it was widely assumed that the formal EMS would be of interest and benefit only to large corporations; however, the reality is the EMSs are being implemented by facilities of all sizes and various sectors [15], although the uptake of EMSs by SMEs is low [11].

It is important to be aware that the drivers as well as the barriers for EMS implementation are different for corporate companies and for the SMEs. An assessment of the previously listed general drivers to the case of SMEs shows that:

- Corporate policies are not a relevant driver for an SME, which, by definition, is privately owned.

- Regulatory expectations are an important external driver.

- Market forces are exhibited for SMEs mostly through customer demands; SMEs are often positioned in the middle of the supply chain; therefore an improved public image is often not a driver of EMS adoption.

- Government assistance: providing aid during the EMS implementation is important for SMEs, as they typically lack human resources; however, is should be carried out in an appropriate way, eg by network, or sector-specific approaches [9].

- Cost reduction is an important internal driver for every business entity.

- Organisational culture may be a driver or a barrier, depending on the SME.

The most important internal barriers encountered among SMEs are [11]:

- lack of human resources, an internal barrier which is often more important than the financial aspect;

- lack of information about EMSs and their benefits;

- employees' and owners' attitudes; and

- company culture.

The most important external barriers are

- problems/dissatisfaction with certification process;

- high implementation costs;

- uncertainty about market benefits of the EMS, as SMEs are often positioned inside the supply chain;

- lack of sector-specific guidance.

There is a general consensus that internal drivers and barriers are more important as the external for SMEs as well as for large companies [9, 11].

\subsection{Construction sector and EMS implementation}

The following barriers valid for the case of construction industry were identified during the discussion with practitioners as well as in the literature [18-20]:

Client's role: his role in the construction project needs to be recognised as a crucial factor that influences also the site and organisation management systems [20].

Subcontracting system: typically, several subcontracting companies participate in a construction project. This creates an additional difficulty in the QMS and EMS implementation of the main contractor, as several organi- 
sations (often small companies) work simultaneously on one site.

Separate design and building: compared to industrial production, traditional separation of the design and building process is a unique feature of a construction project which represents a special challenge for the contractor. This feature is eliminated only when "designbuild" method is chosen as the project delivery method $[21,22]$. When traditional delivery methods are used, the contractor has no influence upon the design, including the choice of materials and components, which may restrict the potential of his EMS.

Lack of environmentally sound materials and technologies: often, the contractor is not able to properly identify and reduce his environmental impacts, as the available database regarding materials and technologies is insufficient to establish a level of environmental soundness.

Lack of worker support: the educational level of a large number of workers taking part in a typical construction project is usually low, therefore they may not recognise the importance of the environmental problems, nor be willing to participate in the actions required by the environmental management, as it takes their additional efforts.

Magnitude of costs related to EMS implementation: implementation of an EMS, similarly to the implementation of a QMS, costs money. This expense may be viewed as unnecessary if general environmental culture in a certain sector /country is low, and there is no incentive from the government. Common sense and observation also allow to point out that weak environmental culture among competitors and lack of governmental pressure are possible barriers.

EMS standards unsuitable for construction: this is again a barrier specific to construction industry. Contractors may perceive general EMS standards as unpractical for use in construction due to its special characteristics (as discussed in the first section of this paper).

Extensive documentation: a construction project is a fairly complex as well as a dynamic process. Therefore any additional documentation required neither by the regulations nor by the contract may be viewed as unnecessary, and perceived as an obstacle to the implementation of the EMS.

No competitor starts first: construction industry is highly competitive, and any additional cost generated within the company without visible financial gain, such as the cost of establishing the EMS, may be viewed as a factor of reducing the profit margin or the chance of winning a project.

\section{The survey}

\subsection{Questionnaire}

In order to obtain the data, a questionnaire consisting of 24 questions was sent to 56 Slovenian construction and engineering companies. The addresses were selected from the membership list of the Slovenian Chamber of Commerce - Construction Department. A total of 28 questionnaires were returned. One questionnaire was returned empty, with the explanation the company was going through bankruptcy, and one was filled out only partially. Three companies chose not to answer one question, notwithstanding, their questionnaires were assumed to be complete. In summary, 26 questionnaires were duly completed and returned, which gives a return rate of $47 \%$. Authors reporting on similar studies recorded similar (eg [19]) or lower return rates (eg [20, 23]).

The implementation of quality management system (QMS) and environmental management system is often linked, therefore a brief section addressing the QMS implementation was included in the questionnaire.

The questionnaire was divided into three main sections:

- general data (main business activity, number of employees, ...),

- quality management (quality policy, QMS implementation, ...) and

- environmental management (environmental policy, main environmental issues, EMS implementation, barriers in the EMS implementation).

\subsection{Results and discussion}

\subsubsection{Company profile and size}

The response to the questionnaire indicates that $76 \%$ of the companies are predominantly general contractors, $12 \%$ state that their predominant activity is construction products manufacturing, and $6 \%$ are engineering companies. A quarter of the respondents state that their only business activity is construction.

The number of employees in participating companies is presented in Table 2. The largest proportion of the responding companies employ between 50 and 200 persons, and $11,5 \%$ have less than 50 employees. It is worthwhile to note the two largest Slovenian construction companies, which participated in the survey, as was already mentioned, each has a workforce of more than 1000 employees. This means that $61,5 \%$ of the responding companies are classified as SMEs.

Table 2. Number of employees of the participating companies

\begin{tabular}{ccc} 
No of employees & No of respondents & $\%$ \\
\hline $0-50$ & 3 & 11,5 \\
$50-200$ & 13 & 50,0 \\
$200-500$ & 8 & 30,8 \\
$500-1000$ & 0 & 0,0 \\
$>1000$ & 2 & 7,7 \\
\hline total & 26 & 100,0 \\
\hline
\end{tabular}

\subsubsection{Quality management}

Quality management is important for the environmental management from the point of view that it is much easier to implement an EMS if there is already an existing QMS, especially if they are both standardised according to the ISO 9000 and 14000 series, respectively [24]. 
The obtained answers show that $88 \%$ of the respondents have an ISO 9001 certified QMS. Only one responding company has a non-standardised QMS, and $8 \%$ of the respondents do not have a QMS. Most of the companies $(65 \%)$ had their own QMS before implementing the ISO 9001 standard, and they could keep a major part of that system when the ISO 9001 was introduced into the organisation.

Furthermore, the attitude of the clients towards quality management was examined (Table 3 ). The results show that a vast majority of responding contractors is faced with the requirement of holding an ISO 9001 certificate from the client. Only $12 \%$ of the respondents claim their clients do not require an established QMS.

Table 3. Attitude of clients towards quality management systems in contracting companies

\begin{tabular}{ccc} 
Clients requiring QMS & No of respondents & $\%$ \\
\hline no & 3 & 12,0 \\
sometimes & 13 & 52,0 \\
yes & 9 & 36,0 \\
\hline total & 25 & 100,0 \\
\hline
\end{tabular}

\subsubsection{Environmental management}

The core section of the questionnaire consisted of questions related to the environmental management; it shows that $77 \%$ of the respondents (ie 20 companies) have an established environmental policy. This number is not much lower than the rate of companies having a quality policy (96\%) and shows a fairly high environmental awareness in the Slovenian construction industry. Only respondents with an environmental policy were asked to answer the subsequent questions.

One of the goals of the survey was to determine the environmental issues the respondents are focussing on. The respondents were asked to rank the following issues:

- energy savings,

- recycling of materials,

- waste control,
- noise reduction,

- air/water pollution reduction.

These issues should be ranked according to one receiving most (rank 1) to least attention (rank 5). Rank 1 scored 1,5 points, and ranks 2, 3, 4, and 5 scored 1,25, $1,0,0,75$ and 0,5 points, respectively. Out of the 20 respondents, 14 respondents ranked the options listed above, and 6 respondents indicated the issues they were tackling but did not rank them. In this case, each answer received 1 point. The scores received for each optional answer from all respondents were summed together to obtain the total score, and the results are presented in Fig 2.

It can be seen that waste control is the environmental issue for which the responding companies are placing the main emphasis. This result can be explained by several reasons. First, since quantities of the construction and demolition waste produced are large, its control can contribute not only to a better quality environment but also to a reduction of costs. Secondly, a new regulation on construction and demolition waste management came recently into power, thus this issue attracted attention of the construction industry in general. Energy savings and air/water pollution reduction are the second most important environmental issues for the companies participating in the survey. Again, these are two issues that are to some extent related to cost savings and legal requirements; therefore they yield enhanced motivation to rank them as a high priority. The respondents who chose to add other central environmental issues quote issues like improving public image, ecosystem preservation, separated collection of waste and cost reduction.

The number of companies with an implemented EMS is presented in Table 4, which shows that 14 out of 20 respondents with an established environmental policy have implemented an EMS. Out of the 6 companies without an EMS, 4 respondents intend to establish an EMS in the near future. This result is encouraging. It shows that the environmental awareness in Slovenian construction sector is increasing. It should also be noted that all companies holding the ISO 14001 certificate are

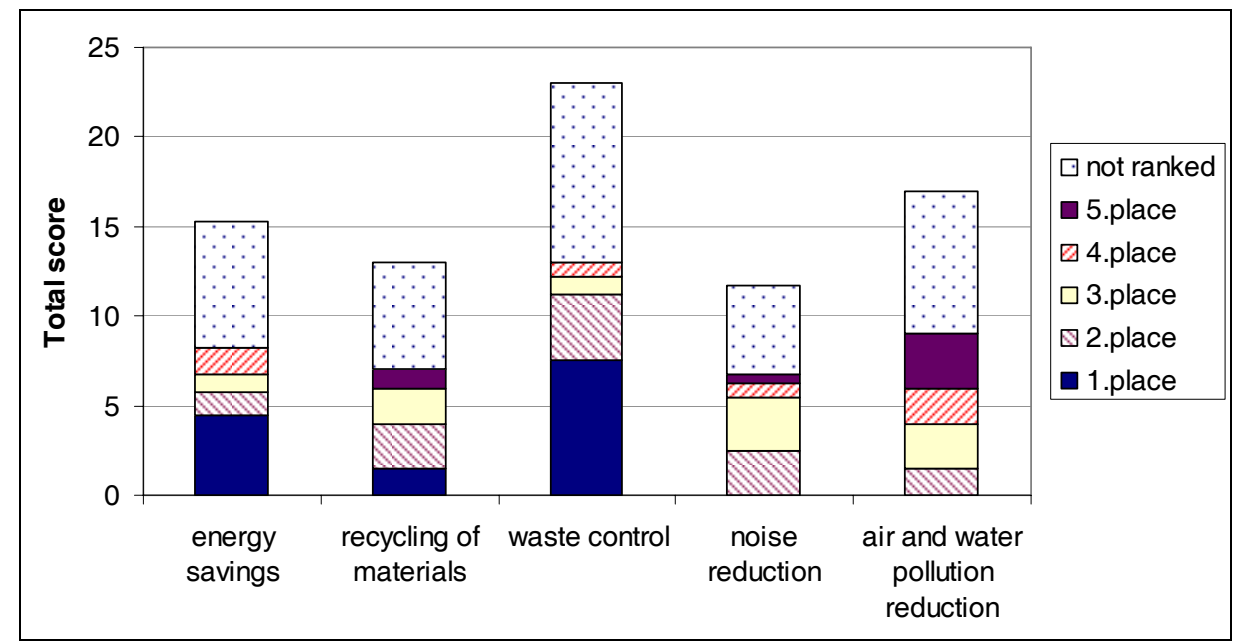

Fig 2. Contributions to total score of optional environmental issues to which the responding companies are focussing on 
also holding the ISO 9001 certificates. This confirms that it is easier to establish an EMS if the framework set by the standardised QMS is already in place. Therefore it is worthwhile to encourage the organisations to start with the implementation of a QMS as the first step to the environmental management system.

Table 4. Implementation of EMSs

\begin{tabular}{|c|c|c|}
\hline & & No of respondents \\
\hline No env. policy & 6 & \\
\hline Existing env. policy & 20 & \\
\hline no EMS & & 6 \\
\hline EMS & & 14 \\
\hline & $\begin{array}{l}\text { informal } \\
\text { EMS }\end{array}$ & 2 \\
\hline & ISO 14001 & 12 \\
\hline Total & 26 & \\
\hline
\end{tabular}

The majority of respondents had elements of EMS before implementing the ISO 14001, and could use them in the certified system. Only $17 \%$ of them did not have the EMS prior to seeking the certification.

The next question was addressed to find out how the respondents dealt with their own environmental problems. The survey results show that 19 organisations, or $73 \%$ of all respondents, compiled a list of environmental potentially problematic issues. It is obvious that all responding organisations holding the ISO 14001 certificate have such list, as this is the standard requirement. Similarly, 18 responding companies (69\%) follow the environmental legislation and are documenting the follow-up. This shows that even the organisations without ISO 14001 but having an environmental policy do use elements of an EMS in their practice.

The final question deals with possible barriers that can be encountered during the implementation of an EMS and are mostly specific for the construction industry.
A list of potential obstacles relevant for the construction industry was compiled based on the literature survey conducted. The list is summarised in Table 5 and it is ordered in importance level as perceived by the companies participating in the survey. The respondents were asked to assess the obstacles and rank them on a Likert scale from 1 (least important) to 5 (most important). A similar list was also used in the study carried out in Hong Kong [19].

An average grade was calculated from the grades given to each answer in Table 5 by the respondents. The results are also presented in Fig 3, and they show that Slovenian construction companies perceive the initial cost and the extensive documentation required as the two major obstacles to EMS implementation. It is interesting to note that in the respondents' view, there is enough pressure from the government in the shape of new regulations, and the general form of the ISO 14001 standard is not perceived as a major obstacle.

Table 5. List of perceived barriers in implementing an ISO 14001-compliant EMS

\begin{tabular}{cl}
\hline 1 & Expensive implementation cost \\
2 & $\begin{array}{l}\text { Complex documentation process } \\
\text { Weak environmental culture among other competi- } \\
\text { tors }\end{array}$ \\
4 & $\begin{array}{l}\text { Sub-contracting system created difficulty to mana- } \\
\text { ge the EMS }\end{array}$ \\
5 & Lack of client requirement supports \\
6 & Separate design and build \\
7 & $\begin{array}{l}\text { Lack of environmentally sound technology/building } \\
\text { materials }\end{array}$ \\
8 & Lack of worker support \\
9 & $\begin{array}{l}\text { Unsuitable standards (different to interpret in const- } \\
10\end{array}$ \\
11 & Lack of governmental pressure \\
\end{tabular}

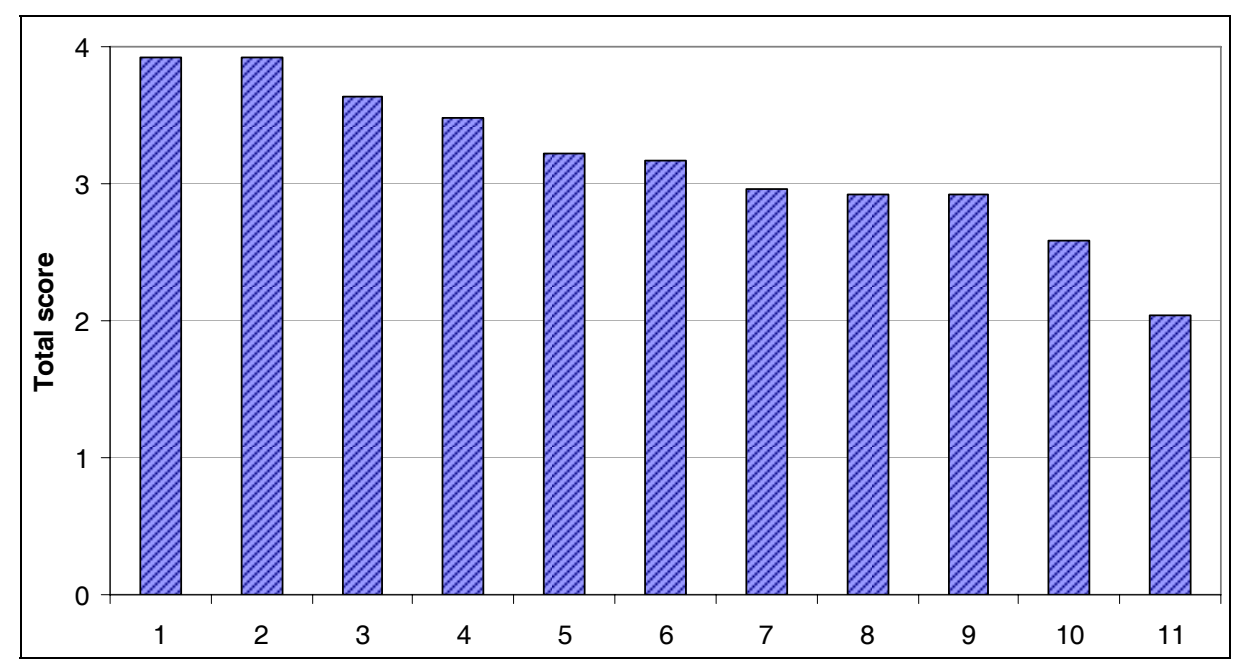

Fig 3. Importance of barriers to implementation of ISO 14001 as perceived by the respondents: 1 - expensive implementation cost , 2 - complex documentation process, 3 - weak environmental culture among other competitors, 4 - sub-contracting system created difficulty to manage the EMS, 5 - lack of client requirement supports , 6 - separate design and build, 7 - lack of environmentally sound technology/building materials, 8 - lack of worker support , 9 - unsuitable standards (different to interpret in construction industry), 10 - lack of governmental pressure, 11 - no competitor takes action first 


\subsubsection{Comparison of SMEs and large companies attitudes}

In order to determine the differences in the attitudes of SMEs and large companies, the survey results were analysed in terms of the company size. The outcome of the analysis is presented in Tables 6,7 and 8. As shown in Table 6, out of 16 SMEs participating in the survey, only $12(75 \%)$ had an established environmental policy, and 5 had EMS as well. Within the group of large companies (10 respondents), 9 companies $(90 \%)$ have the environmental policy and an EMS. These results show that the frequency of the EMS in SMEs is lower.

What concerns the relative importance of environmental issues (Table 7), it can be seen that waste control is important for all respondents regardless of their size. Energy savings, however, seem to be more important for large companies. There was no significant difference in the perceived importance of other environmental issues. SMEs considered complex documentation that accompanies the implementation of an EMS the largest barrier, while for the large companies, costs associated with the implementation process are perceived as the critical factor (Table 8). The relations with the subcontractors on the site and weak environmental culture among competitors are perceived as a reasonably important obstacle for SMEs as well as for large companies. Lack of governmental pressure and the fact that no competitor starts first were perceived as small barriers for all categories under consideration.

Table 6. Number of respondents with environmental policy (EP), EMS and ISO 14001-compliant EMS with respect to the company size

\begin{tabular}{cc|ccc}
\hline & & \multicolumn{3}{|c}{ No of respondents } \\
\hline $\begin{array}{c}\text { Company } \\
\text { size }\end{array}$ & $\begin{array}{c}\text { No of re- } \\
\text { spondents }\end{array}$ & $\begin{array}{c}\text { with } \\
\text { EP }\end{array}$ & EMS & $\begin{array}{c}\text { EMS- } \\
\text { ISO14001 }\end{array}$ \\
\hline $0-50$ & 3 & 1 & 0 & 0 \\
$50-200$ & 13 & 10 & 5 & 5 \\
\hline $200-500$ & 8 & 7 & 7 & 5 \\
$>1000$ & 2 & 2 & 2 & 2 \\
\hline total & 26 & 20 & 14 & 12 \\
\hline
\end{tabular}

Table 7. Importance of environmental issues with respect to the company size

\begin{tabular}{|c|c|c|c|c|c|c|}
\hline 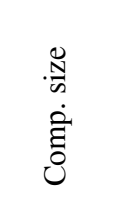 & 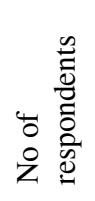 & $\begin{array}{l}\overrightarrow{0} \\
\vec{D} \\
\overrightarrow{\mid=1}\end{array}$ & 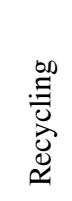 & 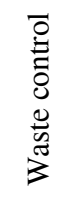 & 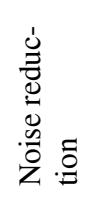 & 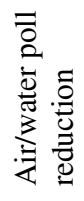 \\
\hline $0-50$ & 1 & & & 1,00 & & 1,00 \\
\hline 50-200 & 10 & 0,58 & 0,70 & 1,20 & 0,53 & 0,88 \\
\hline $200-500$ & 7 & 1,04 & 0,64 & 1,11 & 0,79 & 0,89 \\
\hline$>1000$ & 2 & 1,12 & 1,00 & 1,25 & 0,50 & 0,88 \\
\hline total & 20 & 0,76 & 0,65 & 1,15 & 0,59 & 0,85 \\
\hline
\end{tabular}

Table 8. Importance of perceived barriers with respect to company size

\begin{tabular}{c|cccc}
\hline & \multicolumn{4}{|c}{ Company size } \\
$\begin{array}{c}\text { Barrier } \\
\text { No }\end{array}$ & $0-50$ & $50-200$ & $200-500$ & $>1000$ \\
\hline 1 & 4,00 & 3,92 & $\mathbf{3 , 8 8}$ & $\mathbf{4 , 0 0}$ \\
2 & $\mathbf{4 , 3 3}$ & $\mathbf{4 , 2 5}$ & 3,50 & 3,00 \\
3 & 3,33 & 3,75 & 3,50 & $\mathbf{4 , 0 0}$ \\
4 & 4,00 & 3,58 & 3,13 & 3,50 \\
5 & 3,00 & 3,33 & 3,29 & 2,00 \\
6 & 2,50 & 3,50 & 3,00 & 2,50 \\
7 & 3,33 & 3,17 & 2,50 & 3,00 \\
8 & 2,33 & 3,08 & 3,00 & 2,50 \\
9 & 3,33 & 2,83 & 3,00 & 2,50 \\
10 & 2,33 & 2,58 & 2,86 & 2,00 \\
11 & 2,33 & 2,09 & 2,00 & 1,50 \\
\hline
\end{tabular}

\section{Conclusions}

One of the ways to use the principles of sustainable development in practice and to manifest the increasing environmental awareness at the company's level is implementation of the environmental management system (EMS). The most widely established standard for the EMS is ISO 14001.

Slovenia, as a new member of the European Union, is promoting these principles as well. It is therefore no surprise that the general environmental awareness is growing. Within any sector, small and medium enterprises represent a particularly important group due to their large number, total revenues and number of employees. Different reports suggest that the outreach to this group should be different and sector-specific from the general approach to promote sustainability. The purpose of the reported study was to investigate whether the construction SMEs perceive different barriers in EMS implementation, and whether they concentrate on different environmental issues as large contracting companies. The investigation was carried out within Slovenian construction industry, which was considered as a representative sample of construction industries of new EU members.

When the systems comply to the ISO 9001 and 14001 standards, it is easier to establish the EMS if the QMS is already in place. Therefore, the survey conducted referred also to quality management and QMS. 88\% of the respondents claim that they are faced by the clients' requirements to have the ISO 9001 certificate. As this is the same proportion as the percentage of companies holding the certificate, it can easily be derived that the role of the client is vital in motivating the companies to implement the QMS. Combining this conclusion with the fact that companies having the ISO 9001-compliant QMS are better equipped to start implementing an ISO 14001compliant EMS, we can conclude that promoting ISO 9001 within industry could be also the first step in promoting the ISO 14001 standard, and that the role of the client is crucial in the EMS implementation as well. 
Furthermore, the survey results show that a large proportion of responding companies $(77 \%$ ) has established an environmental policy, which is a first step in environmental management. The environmental issues all these companies are focusing on most are waste control, energy savings and air/water pollution reduction. Differences are observed between SMEs and large companies, as some issues, such as energy savings, are more important for large companies. Handling of all these issues is most likely triggered by the changing legal regulations in respective fields. $46 \%$ of the respondents participating in the survey have an ISO 14001 compliant EMS, and $8 \%$ have a non-standardised EMS. $35 \%$ of the respondents claim that they will start to implement the ISO 14001compliant EMS in the near future. It is also important to note that all the responding companies that hold the ISO 14001 certificate are also in possession of the ISO 9001 certificate. This is a practical proof that it is easier to implement the EMS if QMS is already established. The share of companies with an EMS is higher for large companies, which further confirms that the outreach should be targeted more specifically towards the SMEs. Certain differences are observed among the perceived barriers in the EMS implementation between SMEs and large companies, namely, additional complex documentation associated with the EMS implementation is seen as the largest barrier for the SMEs. This barrier could be overcome if the approach used in the incentives provided by the governmental and other agencies included sector-specific guidelines for EMS documentation. The other important barrier perceived by both categories is cost. Objectively, although it is clear that investments on resources and time are inevitable to establish the EMS, it may not be true that these costs are excessive.

The obtained results show a reasonably high environmental awareness of responding companies. One could argue that companies holding the ISO 9001/14001 certificates are more likely to take part in the survey, and that the sample of the responding companies is not representative. Even so, the percentage of returned questionnaires is high and gives us an insight into the quality and environmental management trends in Slovenia. Further, the analysis of the driving forces to establish a QMS/EMS shows that client and its requirements play a vital role in spreading these systems in construction industry that cannot be overestimated, even when the fact that the client must adapt the environmental awareness as a project objective has been already discussed in the past.

\section{Acknowledgement}

The author thanks Prof Antonio C.M. Sousa for the review and suggestions. The financial support provided by the Slovenian Ministry of Higher Education, Science and Technology through the Research Grant No P2-0185 and Slovenian Construction Cluster is gratefully acknowledged.

\section{References}

1. KEIN, A. T. T.; OFORI, G.; BRIFFETT, C. ISO 14000. Its relevance to the construction industry of Singapore and its potential as the next industry milestone. Construction Management and Economics, 1999, 17(4), p. 449-461.

2. MELNYK, S. A.; SROUFE, R.; CALANTONE, R. Assessing the impact of environmental management systems on corporate and environmental performance. Journal of Operations Management, 2003, 21(3), p. 329-351.

3. Our common future. World Commission on Environment and Development, Oxford Press, UK, 1987. 416 p.

4. BS 7750. Specification for environmental management systems. British Standards Institution, London, UK, 1992.

5. ISO 14001. Environmental management systems requirements with guidance for use. International Standards Organization, Geneva, Switzerland, 2004.

6. The ISO survey of ISO 9000 and 14001 Certificates. 12 cycle. International Standards Organization, Geneva, Switzerland, 2003.

7. ISO survey of certifications 2005. International Standards Organization, Geneva, Switzerland, 2006.

8. CIB Report Publication 237. Agenda 21 on sustainable construction. International Council for Building, Rotterdam, Netherlands, 1999.

9. Successful practices on environmental management systems in small and medium-size enterprises: A North American perspective. Commission for Environmental Cooperation, Montreal, Canada, 2005. (accessible at www.cec.org/files/pdf/ lawpolicy/ems-report_en.pdf)

10. HILLARY, R. Small and medium sized enterprises and the environmental management systems: experience from Europe. Network for Environmental Management and Auditing, London, UK, 2000 (accessible at http://www.iwoe.unisg.ch/org/iwo/web.nsf/66431a87ff21 c36ac12569f50045e850/b0b82add9767ee47c1256a1c 0047f928/ \$FILE/ SGU_Hi.pdf)

11. Public policy initiatives to promote the uptake of environmental management systems in small and mediumsized enterprises. Final report of the BEST project expert group, 2004 (accessible at http://ec.europa.eu/enterprise/ environment/events/ sme_conference/presentations/best_ report_en.pdf)

12. Business indicators for 2004. Slovenian Chamber of Commerce. Ljubljana, Slovenia, 2005 (in Slovenian).

13. PORTER, M. E. America's greening strategy. Scientific American, 1991, 264(4), p. 168.

14. KLASSEN, R. D. AND MCLAUGHLIN, C. P. The impact of environmental management on firm performance. Management Science, 1996, 42(8), p. 1199-1214.

15. Drivers, designs and consequences of environmental management systems. A research compendium. University of North Carolina at Chapel Hill and the Environmental Law Institute, 2001 (accessible at http://ndems.cas.unc.edu/)

16. KLASSEN, R. D. AND WHYBARK, D. C. The impact of environmental technologies on manufacturing performance. Academy of Management Journal, 1999, 42(6), p. 599-615.

17. SROUFE, R. Effects of environmental management systems on environmental management practices and operations. Production and Operations Management, 2003, 12(3), p. 416-431. 
18. CHRISTINI, G.; FETSKO, M. and HENDRICKSON, C. Environmental management systems and ISO 14001 certification for construction firms. ASCE Journal of Construction Engineering and Management, 2004, 130(3), p. 330-336.

19. TSE, R. Y. C. The implementation of EMS in construction firms: case study in Hong Kong. Journal of Environmental Assessment and Policy Management, 2001, 3(2), p. 177-194.

20. OFORI, G.; BRIFFETT, C.; GANG, G. and RANASINGHE, M. Impact of ISO 14000 on construction companies in Singapore. Construction Management and Economics, 2000, 18(8), p. 935-947.

21. HEGAZY, T. Computer-based construction project management. Prentice Hall, 2002. 398 p.
22. LING, F. Y. Y.; CHAN, S. L.; CHONG, E. and EE, L. P. Predicting performance of design-build and design-bidbuild projects. ASCE Journal of Construction Engineering and Management, 2004, 30(1), p. 75-83.

23. ZENG, S. X.; TAM, C. M.; DENG, Z. M. and TAM, V. W. Y. ISO 14000 and the construction industry: survey in China. ASCE Journal of Management in Engineering, 2003, 19(3), p. 107-115.

24. GRIFFITH, A. Integrated management systems: a single management system for project control? Engineering, Construction and Architectural Management, 2000, 7(3), p. 232-240.

\section{APLINKOS VALDYMO SISTEMA BEI MAŽŲ IR VIDUTINIŲ IMONIŲ STATYBA: SLOVÉNIJOS PAVYZDYS \\ J. Šelih}

Santrauka

Statybos projektai ir veikla apskritai yra siejami su įvairiapusišku poveikiu aplinkai. Todèl subalansuotos plètros principai turi būti diegiami statybose, kaip ir bet kuriame kitame pramonès sektoriuje. Organizaciniu lygiu vienas iš būdų pasiekti tikslą yra aplinkos valdymo sistemos diegimas. Pagrindinis šio straipsnio tikslas yra supažindinti su dabartinėmis aplinkos valdymo tendencijomis, vyraujančiomis statybos i̇monėse, remiantis neseniai atliktais tyrimais Slovènijoje, bei pateikti informaciją, kaip mažos ir vidutinio dydžio i̇monès įveikia kliūtis, atsirandančias diegiant aplinkos valdymo sistemą. Taip pat šiame straipsnyje aptariama nauda ir kliūtys, susijusios su ISO 14001 aplinkos valdymo sistemos igyvendinimu, bei pateikiami ir analizuojami Slovėijos statybos i̇monėse atlikto aplinkos valdymo sistemos tyrimo rezultatai. Šie rezultatai rodo, kad dauguma didelių tyrime dalyvavusiu imoniu igyvendina Aplinkos valdymo sistema, o $46 \%$ respondentų savo veikloje taip pat įdiegè šią sistemą. Galima teigti, kad mažų ir vidutinio dydžio įmonių su įdiegta Aplinkos valdymo sistema yra mažiau nei didelių kompanijų. Pagrindinè Aplinkos valdymo sistemos igyvendinimo mažose ir vidutinèse i̇monėse kliūtis yra pernelyg dideli dokumentacijos reikalavimai. Gautos išvados yra gana svarbios, nes jomis remiantis galima nustatyti išeities tašką naujoms idejoms, iniciatyvai, kuri skatintų Aplinkos valdymo sistemą diegti mažose ir vidutinèse įmonèse.

Reikšminiai žodžiai: statybos pramonè, mažos ir vidutinės įmonės, aplinkos valdymo sistema, kokybės valdymo sistema, ISO 14000, tyrimas, Slovenija.

Jana ŠELIH. Assistant Professor at University of Ljubljana, Faculty of Civil and Geodetic Engineering where she teaches Construction management. Her research interests include sustainable construction, quality management, maintenance management and decision methods in construction. 